\title{
Investigating the effect of capping agent PVP on the synthesis of silver nanowires by polyol method and its application as flexible transparent conducting electrode
}

\author{
- Hoang Thi Thu \\ - Tran Quang Trung \\ University of Science, VNU-HCM \\ ( Received on March 20th 2013, accepted on March 26 ${ }^{\text {th }}$ 2014)
}

\section{ABSTRACT}

In this report, we present a rapid and efficient polyol method - the solution-phase approach for the large scale synthesis of silver nanowires with diameters in the range of $40-50 \mathrm{~nm}$, and lengths up to $20 \mu \mathrm{m}$. Although the polyol process is a popular method of preparing metal nanostructures, so far most of the published works mainly focused on the synthesis process regardless of amount of surfactants. In this article, we successfully synthesized large-scale uniform silver nanowires with high aspect ratios by introducing the long-chain PVP $(M W=58000)$ and investigated the effect of the amount of PVP on the synthesis of $\mathrm{Ag}$ nanowires by studying their morphologies, structures and optical properties. The dependency of nanowire morphology and

aspect ratio on synthesis parameters was shown via SEM images. The diameter of nanowires decreased when the molar ratio of PVP to silver nitrate was increased. Further more, the molar ratios decided the morphology (particle, rod or wire) of the Silve solution. Synthesized silver nanowires were analyzed by scanning electron microscopy (SEM) and $X$-ray diffraction (XRD). This aqueous dispersions of silver nanowires were used to prepare thin, flexible, transparent, conducting films on polyethylene terephthalate substrate (PET) by spraying method. The prepared silver nanowire films on PET substrate had a transparency of $82 \%$ and sheet resistance of $10 \Omega / \square$.

Keywords: Ag nanowire, polyol method, PVP, silver nitrate.

\section{INTRODUCTION}

The demand for printed electronic devices on plastic substrates has generated a need for solution processable flexible electrodes with high transparency and low sheet resistance.

Conducting polymers, metal inks, nanoparticulate metal oxides, carbon nanotubes, and graphene have been investigated as potential alternatives to brittle indium tin oxide (ITO), but none can yet

Trang 52 
compete in terms of transparency and sheet resistance.

Thin meshes of silver nanowires (Ag-NWs) have recently emerged as promising electrodes due to their ability to provide transmittances greater than $85 \%$ at sheet resistances less than 20 $\Omega$ /sq [2].

For the synthesis of silver nanowires, plenty of chemical routes have been developed during these years. However, soft solution method has been widely considered as the most feasible route to large-scale production of silver nanowires. For the polyol synthesis of silver nanowires (Fig.1), Xia et al [3] had contributed a lot to the basic research and proposed many reasonable and important view-points on the mechanism, which had been widely adopted and accepted by other peer-researchers now [3]. In most of synthetic routes, $\mathrm{AgNO}_{3}$ was usually adopted as the precursor and polyol always acted as both solvent and reducing reagent, while the capping reagent varies in abundance of candidates. After Xia et al detected the presence of glycol aldehyde (GA) in the polyol reactive system the reaction formats were elucidated as follows:

$$
\begin{aligned}
& \mathrm{HOCH}_{2} \mathrm{OH} \rightarrow \mathrm{CH}_{3} \mathrm{CHO}+\mathrm{H}_{2} \mathrm{O} \\
& 2 \mathrm{Ag}^{+}+2 \mathrm{CH}_{3} \mathrm{COOH}_{3}+2 \mathrm{Ag}+2 \mathrm{H}^{+} \\
& 2 \mathrm{HOCH}_{2} \mathrm{CH}_{2} \mathrm{OH}+\mathrm{O}_{2} \rightarrow 2 \mathrm{HOCH}_{2} \mathrm{CHO}+2 \mathrm{H}_{2} \mathrm{O}
\end{aligned}
$$

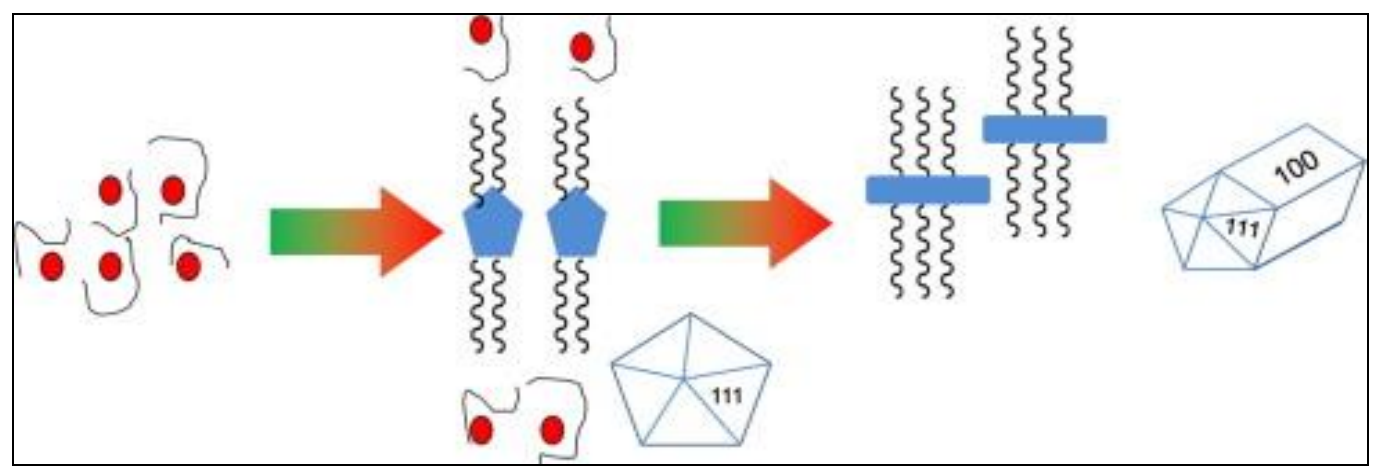

Fig. 1. The growth mechanism of silver nanorods in the nanowire-seeding polyol process [4]

They found that heating ethylene glycol (EG) in air resulted in its oxidative product (GA): a much stronger reductant than acetaldehyde. It was reported that, when temperature of the reactive system was above $150^{\circ} \mathrm{C}$ would become the predominant reductant in the presence of $\mathrm{O}_{2}$. So the reaction format (3) should be added into this reactive system. In addition, they also found the newly formed silver nanoparticles could catalyze the oxidation of $\mathrm{O}_{2}$.

To date, the most popular capping agent is PVP in the synthesis of silver nanowires and its detailed mechanism has not yet been thoroughly studied out. It is believed that silver nanowires are derived from Multiply-Twinned Particles
(MTPs), which are quite different from the ordinary nanoparticles and only can be generated under special situation. As shown in Fig. 1, MTPs are covered by five $\{111\}$ facets at each end and the side surfaces of nanowires are bounded by five $\{100\}$ facets. The anisotropic growth is realized by selectively covering the facets $\{100\}$ with PVP as a result that $\{100\}$ facets are completely passivated, while $\{111\}$ facets are largely bare and still quite active. Hence the reduced silver atoms are preferentially deposited onto $\{111\}$ facets, leading to the anisotropic growth of silver nanowires [3]. 


\section{MATERIALS AND METHODS}

Synthesis of silver nanowire materials with different amounts of PVP

Recently, many research groups have been devoted to explore the synthetic conditions in the presence of PVP or other surfactants to promote the anisotropic growth of silver nanowires preparing by Polyol method.

As above presentation, the Polyol method traditionally needed two steps to synthesize the silver nanowires: seeding process and nanowiresgrowing process. In the first step, $\mathrm{AgNO}_{3}$ (silver nitrate) was reduced to form the nucleus seeds at a quite low concentration. Then the newly generated silver atom would selectively deposit onto the seeds to induce the $1 \mathrm{D}$ growth at a relatively high concentration in the second step. In this report, Ag-NWs were synthesized in solution as shown in Fig. 2. Firstly, a mixture of $17 \mathrm{mg} \mathrm{NaCl}$ and $20 \mathrm{~mL}$ EG (ethylene glycol) in a flask was stirred carefully by ultrasound in 3 minutes and then heated at $100^{\circ} \mathrm{C}$. This temperature is a high enough to enhance the reducing ability of EG (the boiling temperature of $\mathrm{EG}$ is $197.3^{\circ} \mathrm{C}$ ). Secondly, the other mixture of $0.025 \mathrm{~g} \mathrm{AgNO}_{3}$ and $20 \mathrm{~mL} \mathrm{EG}$ was also stirred by ultrasound in 3 minutes and then was added for forming initial silver seeds. The third step, three minutes later, $0.006 \mathrm{~g} \mathrm{KBr}$ (potassium bromide) was added as surface agent and then was heated up to $150^{\circ} \mathrm{C}$. The fourth step, a mixture of $0.3 \mathrm{~g}$ of PVP (poly vinylpyrrolidone) and $20 \mathrm{ml}$ of EG was added and heated and thermally stabilized at $160^{\circ} \mathrm{C}$ in 15 minutes as shown in Fig. 2.

Finally, $0,250 \mathrm{~g}$ of $\mathrm{AgNO}_{3}$ precursor was added in this hot flask to form Ag-NWs. This procedure can be prolonged more than $45 \mathrm{~min}$ to ensure that the NWs growth is complete. During reaction time, this solution turned gradually to grey color. This indicated that Ag-NWS was formed. Then solution was cooled naturally and settled in 12 hours [1].

The extraction procedure of $\mathrm{Ag}-\mathrm{NWs}$ from solution was perfomanced by centrifugate method following 2 steps. Firstly, the cooleddown solution was centrifuged at $6000 \mathrm{rpm}$ for $30 \mathrm{~min}$ to get supernatant containing the long/thin wires and reject solvent (EG), PVP, and other impurities. This supernatant was dissolved in solution and repeatedly centrifuged at 6000 rpm for 30 min to precipitate the wires. Finally, the pure precipitate of Ag-NWs was dispersed in $10 \mathrm{ml}$ of distilled water for storage. It is noticeable that the efficiency of extraction procedure will dependent on centrifugated method.

The absorption, structure and morphology of as-synthesized Ag-NWs was measured and characterized by UV-Vis Jasco V550 spectrometer, XRD Shimadzu 5A and SEM S4800.

Trang 54 

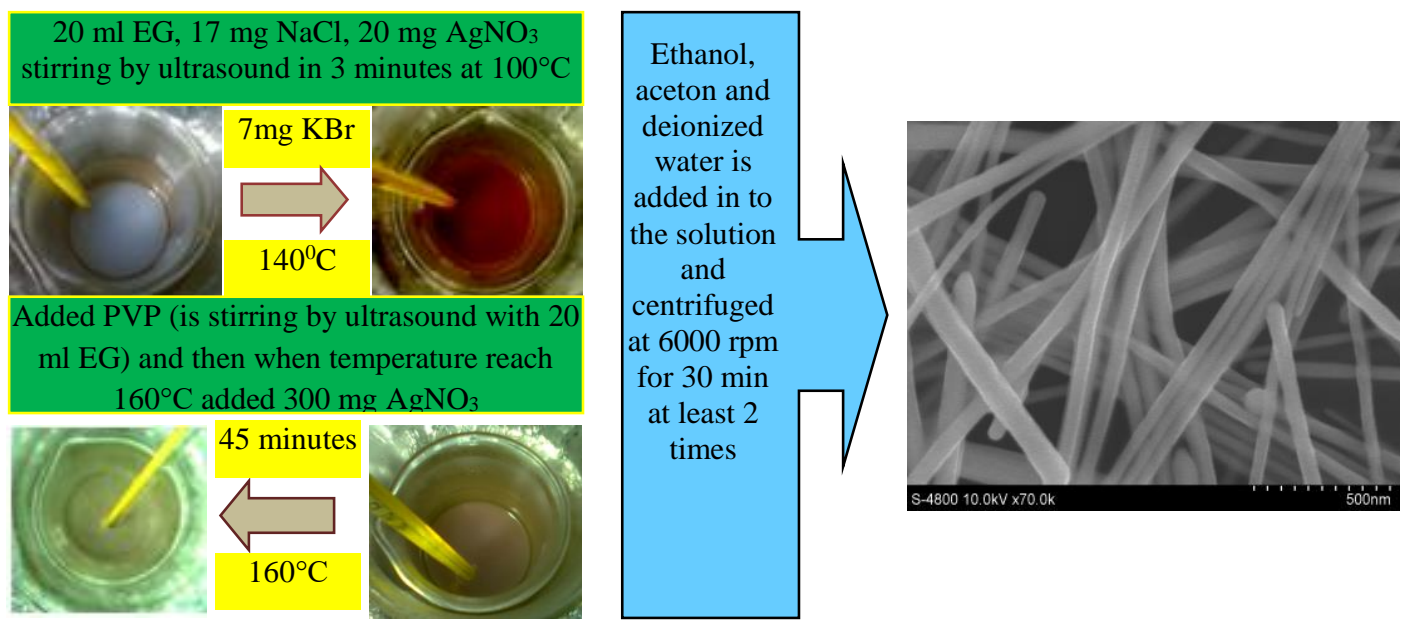

Fig. 2. Fabrication scheme of Ag nanowires by Polyol method

\section{Preparation of thin films of silver nanowires}

The Ag-NWs dispersion was sprayed onto a $1.2 \mathrm{~cm} \times 1.2 \mathrm{~cm}$ preheated PET substrate using an airbrush system with Argon as a carrier gas. An airbrush with a nozzle diameter of $0.2 \mathrm{~mm}$ was set in single action mode to fix a ratio of $\mathrm{Ag}$ NWs dispersion to Argon gas. The inlet pressure of Argon gas was 2 bars. The spraying rate was $0.2 \mathrm{ml} / \mathrm{min}$. The distance between the tip of the nozzle and the substrate was $12 \mathrm{~cm}$. The AgNWs thin layer from spray deposition process was performed by controlling the Argon gas and Ag-NWs dispersion was atomized into small droplets which were carried by Argon gas toward the preheated substrate.

\section{RESULTS AND DISCUSSION}

Investigation of the effect of capping agent PVP on the synthesis of silver nanowires by Polyol method

The absorption spectra in UV-Vis region of the collected Ag-NWs solution not only indicate presence the nanowires of $\mathrm{Ag}$ solution but also estimate amount of nanowires qualitatively as shown in Fig. 3.

Table 1. Synthesic Ag nanowires with respect to different amount of PVP

\begin{tabular}{|c|c|c|c|c|c|}
\hline Sample & $\begin{array}{c}\mathrm{NaCl} \\
(\mathrm{mg})\end{array}$ & $\begin{array}{c}\text { "seed" } \\
\mathrm{AgNO}_{3} \\
(\mathrm{mg})\end{array}$ & $\begin{array}{c}\mathrm{KBr} \\
(\mathrm{mg})\end{array}$ & $\begin{array}{c}\text { PVP } \\
(\mathbf{m g})\end{array}$ & $\begin{array}{c}\mathrm{AgNO}_{3} \\
(\mathrm{mg})\end{array}$ \\
\hline PVP 100 & 17 & 20 & 7 & $\mathbf{1 0 0}$ & 300 \\
\hline PVP 300 & 17 & 20 & 7 & $\mathbf{3 0 0}$ & 300 \\
\hline PVP 600 & 17 & 20 & 7 & $\mathbf{6 0 0}$ & 300 \\
\hline
\end{tabular}

In this absorption spectra, the broading peaks from $330 \mathrm{~nm}$ to $600 \mathrm{~nm}$ is characterized for the absorption of all kind of shape of $\mathrm{Ag}$ as wire or particle containing in solution. Following [1] the characterization peaks of $\mathrm{Ag}$ nanowire and particle are at $370 \mathrm{~nm}$ broading from $330 \mathrm{~nm}$ to $400 \mathrm{~nm}$ and at $410 \mathrm{~nm}$ broading from $380 \mathrm{~nm}$ to $500 \mathrm{~nm}$, respectively. 


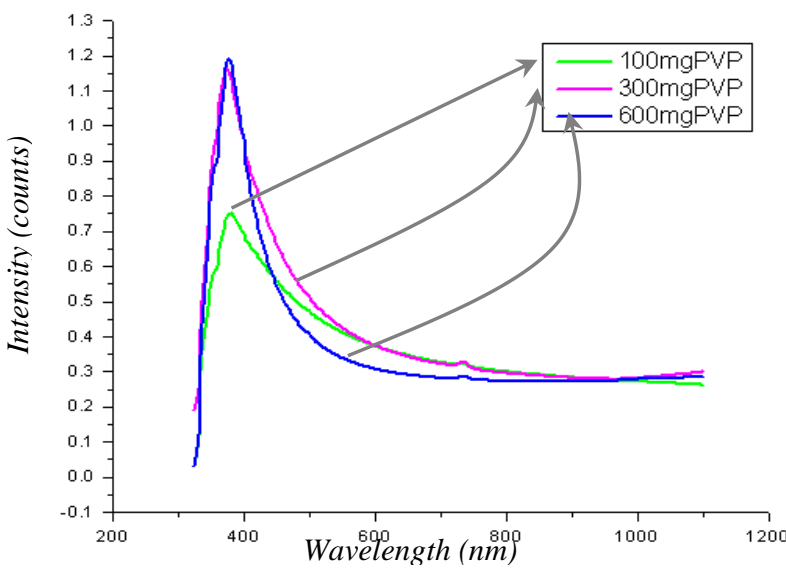

Fig. 3. Absorption spectrum of Ag-NWS with respect to different amounts of PVP
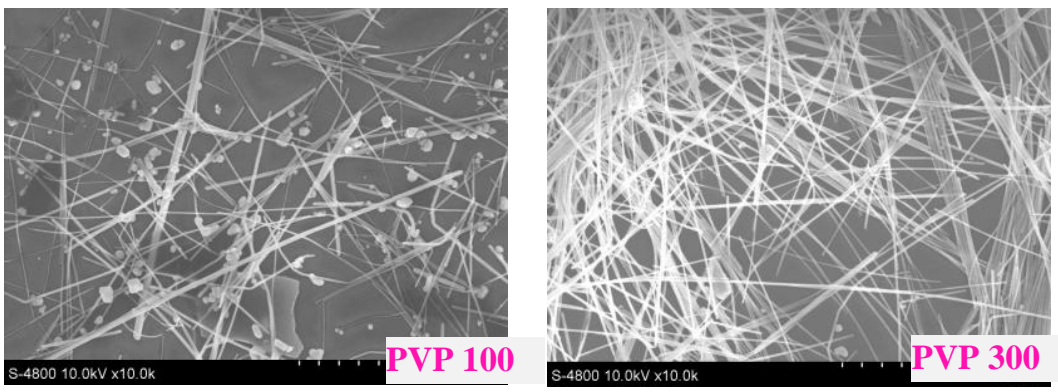

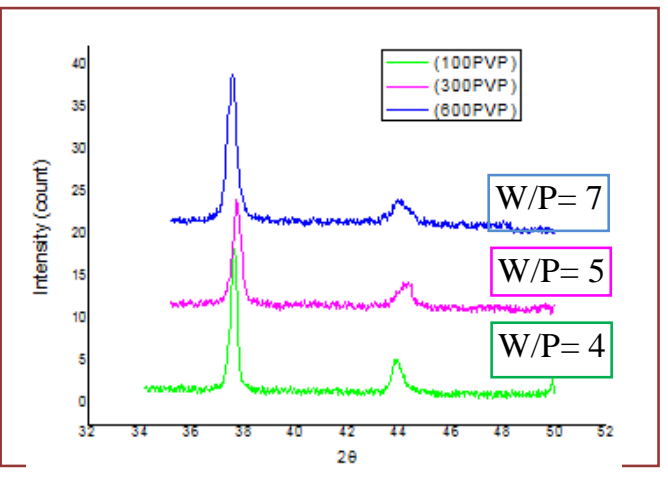

Fig. 4. XRD of Ag-NWS with respect to different amounts of PVP

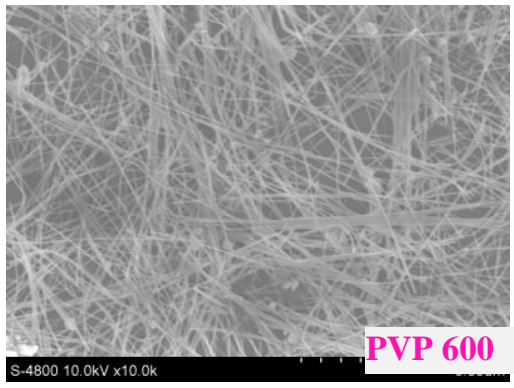

Fig. 5. SEM images of $\mathrm{Ag}$ synthesized at different PVP:AgNO $\mathrm{Amolar}_{3}$ ratios of (a) 1:3, (b) 1:1, (c) 2:1 ( All scales are $5 \mu \mathrm{m}$ ).
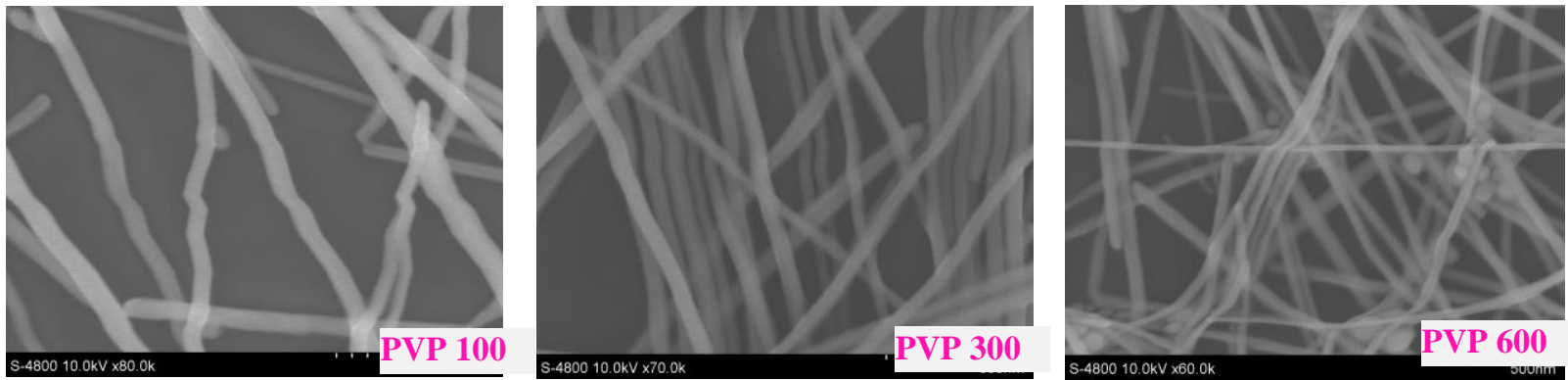

Fig. 6. SEM images of $\mathrm{Ag}$ synthesized at different PVP:AgNO 3 molar ratios of (a) 1:3, (b) 1:1, (c) 2:1 (All scales are 500 $\mathrm{nm})$.

\section{Trang 56}


When silver nitrate was reduced in the presence of seeds ( $\mathrm{Pt}$ or $\mathrm{Ag}$ particles of a few nanometers), silver nanoparticles with a bimodal size distribution were generated in the reaction mixture via heterogeneous and homogeneous nucleation processes, respectively. In the following step, silver nano particles with larger sizes were able to grow at the expense of smaller ones through Ostwald ripening [3]. In the early stage of the ripening process, the majority of larger silver particles could be directed to grow into nanorods with uniform diameters, which could then grow continuously into uniform nanowires of up to $20 \mu \mathrm{m}$ length [1]. This phenomenon was effected strongly by amout of PVP agent in reation procedure. As shown in Fig. 3, 4, 5, 6 the absorption spectra, XRD pattern and SEM images of Ag-NWs samples synthesized with different amount of PVP, illustrated clearly the role of PVP. When the PVP:AgNO $\mathrm{AN}_{3}$ molar ratio increased, the half width of absorption peaks decreased as shown in Fig. 3. Additional, the ratio between $\{111\} /\{200\}$ peaks increased to confirm the huge amount of Ag-NWs were formed as shown in XRD pattern (Fig. 4) and SEM images (Fig. 5).

The final morphologies of $\mathrm{Ag}$ nanostructures at the end of the polyol process were strongly dependent on the PVP: $\mathrm{AgNO}_{3}$ molar ratio. In Fig. 5, 6 panels a-c, SEM images of the nanowires synthesized with different PVP: $\mathrm{AgNO}_{3}$ molar ratios of 1:3, 1:1 and 2:1 were shown, respectively. When the PVP:AgNO3 molar ratio was 1:3, the passivation of $\{100\}$ faces of Multiply-Twinned Particles was insufficient and $\mathrm{Ag}$ nanostructure growth occurred on both $\{111\}$ and $\{100\}$ faces. Under these conditions, Ag nanowires synthesized at low PVP: $\mathrm{AgNO}_{3}$ molar ratios had larger diameters and amount of Ag-NWS was less than those at a high ratio. Moreover, the MultiplyTwinned Particles that could not grow into nanowires agglomerate and form large amounts of biger size $\mathrm{Ag}$ particles. The bigger $\mathrm{Ag}$ particles formation observed in Fig. 5a could be attributed to excess PVP molecules covering all surfaces of $\mathrm{Ag}$ nanoparticles, including the ones that must be left active. These excess PVP molecules were also responsible for blocking anisotropic growth (1D) of Ag nanowires. As the PVP: $\mathrm{AgNO}_{3}$ molar ratio increased, the diameter of the nanowires decreased and amount of collected Ag-NWS increased gradually, as shown in Fig. 6 a-c. Optimum PVP: $\mathrm{AgNO}_{3}$ molar ratio was then determined as 1:1 giving wires with 50nm diameter, as inferred from Fig. 6b. This diameter was consistant with the Plasmon resonance in photovoltaic devices and easily to remove excess product after reaction. Under these conditions, only $\{100\}$ faces of multitwinned particles were passivated, and as the Ag atoms join active (111) planes, longitudinal growth in the [110] direction becomes favorable.

\section{Application of Ag-NWS as flexible transparent conducting electrode}

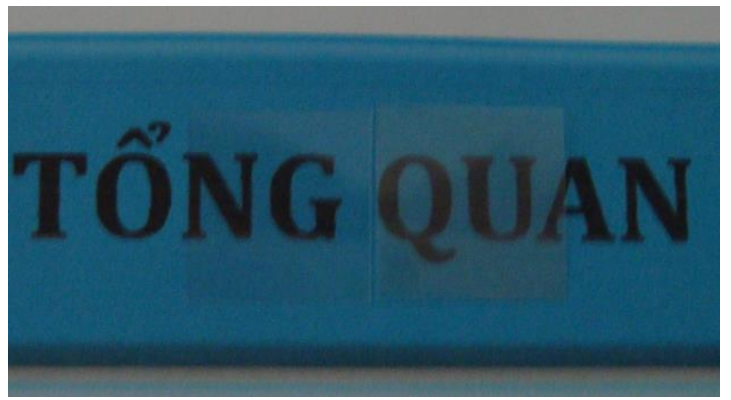

Fig. 7. Photograph of a film of Ag-NWs on PET covering the pictures (right side) with $\mathrm{Rs}=10 \Omega / \square$ coupled with $\mathrm{T}=82 \%$

Organic solar cells (OSCs) offer a promising alternative to inorganic solar cells due to their low cost, easy fabrication, and compatibility with flexible substrates over a large area. However, further enhancement of the PCE is still required for practical applications.

Trang 57 


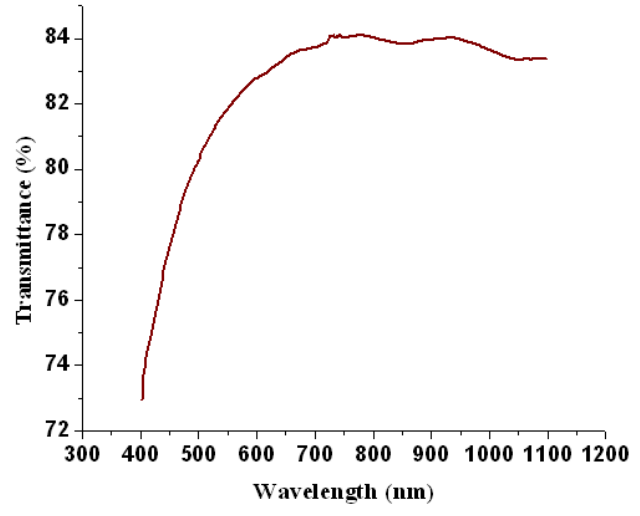

Fig. 8. Transmittion spectra of $\mathrm{Ag}$ nanowires thin film (with $\mathrm{T}=82 \%, \mathrm{Rs}=10 \Omega / \square)$

Since the photo-current of the solar cell is directly related to the light intensity, an effective approach to enhance the efficiency of a thin film organic solar cell is to increase the light absorption of the organic film without having to increase the photoactive layer thickness. This constraint mainly comes from the low carrier mobility of organic materials. For this purpose, several light trapping approaches including a folded configuration, diffraction grating, photonic crystal, and surface plasmon resonance (SPR) have been investigated and have demonstrated promising results. Among these, the SPR is one of the most promising approaches due to the enhanced optical field associated with metallic nanostructures. Surface plasmons (SP) are surface waves whose electromagnetic field is confined to the vicinity of the metal-dielectric interface [9]. When the condition of the resonance is fulfilled, this confinement leads to an enhancement of the electromagnetic field at the interface and this aspect has been utilized in many near-field SP-based applications, such as SP interference lithography, superlens imaging and surface enhanced Raman scattering. With this trend, we have prepared the transparent conductive coating on PET substrate (1.2 x 1.2 $\mathrm{cm}^{2}$ ) by a spraying method. After coating, the sheet resistance of the film was measured by a four-probe method, and its transmittance to light (550 $\mathrm{nm}$ wavelength) by UV-vis spectrometer. The best silver nanowire films on PET substrate are deposited having a transparency of $82 \%$ and sheet resistance of $10 \Omega / \square$.

\section{CONCLUSION}

PVP capping agent (or a polymer other similar features) plays an important role in the synthesis process of silver nanowires by Polyol method. Many scientists believe that the anisotropic growth is realized by selectively covering the facets $\{100\}$ with PVP as a result that $\{100\}$ facets are completely passivated, while $\{111\}$ facets are largely bare and still quite active. Hence the reduced silver atoms are preferentially deposited onto $\{111\}$ facets $[1,3,4]$.

Our results showed that when a higher PVP:AgNO $\mathrm{A}_{3}$ molar ratios was used the diameter of the nanowires decreased and amount of collected Ag-NWS increased gradually. The high amount of PVP also decreased the harvest of AgNWS from synthesis procedure because of the difficulties in washing and centrifugal filter process. The best silver nanowire films deposited on PET substrate had a transparency of $82 \%$ and a sheet resistance of $10 \Omega / \square$. With such results, these films can be considered as an alternative option to Indium tin oxide on PET as transparent flexible electrodes.

\section{ACKNOWLEDGEMENTS}

This work was funded by Vietnam National University Ho Chi Minh City (Grant No. C2014-18-24)

\section{Trang 58}




\section{Khảo sát ảnh hưởng của tác nhân capping PVP lên quy trình tổng hợp dây nano bạc bằng phương pháp polyol và ứng dụng làm điện cực trong suốt dẫn điện trên đế dẻo}

- Hoàng Thị Thu

- Trần Quang Trung

Trường ĐH Khoa học Tự nhiên, ĐHQG-HCM

\section{TÓM TÁT}

Trong bài báo này chúng tôi trình bày phương pháp Polyol một phương pháp nhanh và hiệu quả, để chế tạo các sợi nano bạc có đường kính trong khoảng 40-50 nm và chiều dài có thể lên đến $20 \mu \mathrm{m}$. Mặc dù phương pháp Polyol rất thông dụng để chế tạo các vật liệu kim loại cấu trúc nano, song hầu hết các bài báo đã xuất bản chỉ tập trung vào các quá trình chế tạo mà bỏ qua lượng chất hoạt động bề mặt. Trong bài báo này chúng tôi đã chế tạo thành công một số Iượng lớn các sợi nano bạc đồng đều với tì số chiều dài trên đường kính khá cao khi cho thêm hoạt chất PVP (có khối lượng mol là 58 000) vào quá trình chế tạo và chúng tôi cũng đã khảo sát những ảnh hưởng của PVP lên việc tổng hợp sợi nano bạc dựa trên hình thái học bề mặt, cấu trúc và tính chất quang

\section{REFERENCES}

[1]. T. Thu, T.Q. Trung, Preparation of silver nanowires by polyol method and their application for transparent conducting electrode, Journal of Science and Technology (SPMS), 50 (1B), 472-480 (2012). của chúng. Sự phụ thuộc hình thái học của sợi bạc vào lượng PVP và tỉ số tối ưu của nó được minh chứng qua ảnh SEM. Chúng tôi nhận thấy rằng đường kính của sợi nano bạc giảm đi khi tăng tỉ số mol giữa $\mathrm{PVP} / \mathrm{AgNO}_{3}$. Ngoài ra, tỉ số này còn quyết định hình thái học cuối cùng của dung dịch nano bạc là dạng hạt, dạng thanh hay dạng sợi. Hình thái học bề mặt và cấu trúc của các sợi nano bạc được phân tích bằng ảnh SEM và phổ nhiễu xạ tia $X$. Phân tán các sợi nano bạc trong nước cất và được dùng để chế tạo màng dẫn điện trong suốt trên đế dẻo (PET) bằng phương pháp phun phủ nhiệt phân. Màng nano bạc trên đế $P E T$ có độ truyền qua $82 \%$ và điện trở mặt là $10 \Omega /$.

[2]. D.S. Leem, A. Edwards, M. Faist, J. Nelson, D.D.C. Bradley, J.C.de Mello, Efficient organic solar cells with solution-processed silver nanowire electrodes, Adv. Mater., 23, 4371-4375 (2011). 
[3]. G. Yan, L. Wang, L. Zhang, Recent research progress on preparation of silver nanowires by soft solution method, Rev. Adv. Mater. Sci., 24, 10-25 (2010)

[4]. Q.A.N. Luu, J.M. Doorn, M.T. Berry, C Jiang, Preparation and optical properties of silver nanowires and silver-nanowire thin films, Journal of Colloid and Interface Science, 356, 151-158 (2011).

[5]. Sukanta De, T.M. Higgins, P.E. Lyons, E.M. Doherty, P.N. Nirmalraj, W. Blau, J.J. Boland, J.N. Coleman, Silver nanowire networks as flexible, transparent, conducting films: extremely high DC to optical, Conductivity Ratios, 3, 1767-1774 (2009).

[6]. L. Hu, H.S. Kim, J.Y. Lee, P. Peumans, Y. Cui, Scalable coating and properties of transparent, flexible, silver nanowire electrodes, ACS Nano, 4, 2955-2963 (2010).
[7]. L. Gou, M. Chipara, J.M. Zaleski, Convenient, Rapid synthesis of Ag nanowires, Chem. Mater., 19, 1755 - 1760 (2007).

[8]. S. Coskun, B. Aksoy, H.E. Unalan, Polyol synthesis of silver nanowires: An extensive parametric study, Cryst. Growth, 11, 49634969 (2011).

[9]. Y. Sun, B. Mayers, Y.N. Xia, Polyol Synthesis of uniform silver nanowires: A plausible growth mechanism and the supporting evidence, Nano Lett., 3, 955-960 (2003).

[10].M.G. Kang, T. Xu, H.J. Park , Efficiency enhancement of organic solar cells using transparent plasmonic $\mathrm{Ag}$ nanowire electrodes $A d v$. Mater. 22, 4378-4383 (2010). 